Pesq. Vet. Bras. 30(7):554-558, julho 2010

\title{
Vaccination protocol and bacterial strain affect the serological response of beef calves against blackleg ${ }^{1}$
}

\author{
Rafael F. Araujo², Vera C.L.M. Curci ${ }^{3}$, Fabiana L.C. Nobrega ${ }^{4}$, Rosa M.M. \\ Ferreira $^{5}$ and Iveraldo S. Dutra ${ }^{5 *}$
}

\begin{abstract}
Araujo R.F., Curci V.C.L.M., Nobrega F.L.C., Ferreira R.M.M. \& Dutra I.S. 2010. Vaccination protocol and bacterial strain affect the serological response of beef calves against blackleg. Pesquisa Veterinária Brasileira 30(7):554-558. Departamento de Apoio, Produção e Saúde Animal, Curso de Medicina Veterinária, Universidade Estadual Paulista, Rua Clóvis Pestana 793, Bloco 37, Araçatuba, SP 16050-680, Brazil. E-mail: isdutra@fmva.unesp.br

The serological response of beef calves was evaluated with different vaccination regimens against blackleg, using an official strain (MT) and a field-collected strain of Clostridium chauvoei as antigens. Sixty calves were randomly allocated to four different groups and were submitted to distinct vaccination protocols with a commercial polyvalent vaccine. Group G1 was first vaccinated at four months of age and a booster shot was given after weaning, at eight months. Group G2 was given the first dose at eight months and a booster shot 30 days later. Group G3 was vaccinated only once at eight months and the control group was not vaccinated. These alternative vaccination regimens were proposed in an effort to adequately protect cattle under open-field farming conditions. Serological evaluations were made by Elisa at 4, 8, 9 and 10 months of age. Both groups receiving booster shots had a significantly increased serological response 30 days later. However, the serum IgG levels against $C$. chauvoei were significantly higher in the calves that were first vaccinated at four months. At 10 months, the two booster shot groups (G1 and G2) had similar serological responses, while the calves that were treated with a single dose of vaccine at weaning (G3) had a response that was similar to that of the control group. The serological response of the calves was significantly inferior at several of the evaluation times when the field strain of the bacteria was used as a challenge antigen instead of the official MT strain. The serological response of calves that are vaccinated twice was found to be satisfactory, independent of the first injection being made at four or eight months of age. It was also concluded that it would be useful to include local bacterial strains in commercial vaccine production.
\end{abstract}

INDEX TERMS: Clostridiosis, Clostridium chauvoei, vaccine, antibody, beef cattle.

\footnotetext{
${ }^{1}$ Received on January 11, 2010.

Accepted for publication on March 19, 2010.

2 Programa de Pós-Graduação em Medicina Veterinária, Área de Medicina Veterinária Preventiva, Faculdade de Ciências Agrárias e Veterinárias, Universidade Estadual Paulista (Unesp), Campus Jaboticabal, Via de Acesso Prof. Paulo Donato Castellane s/n, Jaboticabal, SP 14884-900, Brazil. E-mail: rafaelvetxuxa@bol.com.br

${ }^{3}$ Unidade de Pesquisa e Desenvolvimento de Araçatuba, Agência Paulista de Tecnologia dos Agronegócios (APTA), Av. Alcides Fagundes Chagas 122, Araçatuba, SP 15055-565, Brazil.

${ }^{4}$ Centro de Pesquisa e Desenvolvimento de Imunobiológicos Veterinários, Instituto Butantan, Av. Vital Brasil 1500, São Paulo, SP 05503900, Brazil.

${ }^{5}$ Departamento de Apoio, Produção e Saúde Animal, Curso de Medicina Veterinária, Unesp, Rua Clóvis Pestana 793, Bloco 37, Araçatuba, SP 16050-680. *Corresponding author: isdutra@fmva.unesp.br
}

RESUMO.- [Esquemas de vacinação e cepa bacteriana influenciam na resposta sorológica contra o carbúnculo sintomático em bezerros de corte.] Foi avaliada a resposta sorológica de bezerros de corte submetidos a diferentes esquemas de vacinação contra o carbúnculo sintomático, empregando-se como antígenos duas cepas distintas de Clostridium chauvoei: uma oficial (MT) e a outra uma cepa de campo. Os animais $(n=60)$ foram randomizados em quatro grupos (G1, G2, G3 e Controle) e submetidos a três protocolos distintos de vacinação com um produto comercial polivalente. O G1 foi primovacinado aos 4 meses de idade e recebeu o reforço após desmama (8 meses de idade). O G2 recebeu a primeira dose aos 8 meses de idade e reforço 30 dias após. O G3 foi vacinado somente aos 8 meses de idade e o 
Controle não foi vacinado. As avaliações sorológicas pelo ensaio imunoenzimático (Elisa) foram realizadas aos 4, 8, 9 e 10 meses de idade dos bezerros. Nos dois esquemas em que os animais receberam o booster (G1 e G2), houve um aumento significativo $(p<0,05)$ da resposta sorológica quando foram avaliados 30 dias após. No entanto, os valores séricos de IgG contra $C$. chauvoei foram significativamente maiores nos animais primovacinados aos 4 meses de idade. Aos 10 meses, os dois grupos que receberam o reforco vacinal (G1 e G2) não diferiram entre si na resposta sorológica e os bezerros que receberam uma única dose de vacina na desmama (G3) não diferiu do Controle. A resposta sorológica dos bezerros foi significativamente inferior $(p<0,05)$ em diversos momentos da avaliação, quando a cepa de campo foi empregada como antígeno e quando comparada à da cepa MT. Pode-se deduzir que a resposta sorológica dos bezerros vacinados aos 4 e 8 meses de idade foi satisfatória e que existiram diferenças significativas nos valores séricos de anticorpos contra $C$. chauvoei quando na avaliação foi empregada cepa de campo.

TERMOS DE INDEXAÇÃO: Clostridiose, Clostridium chauvoei, vacina, anticorpos, bovinos de corte.

\section{INTRODUCTION}

Blackleg is a necrotizing myositis that is caused by the activation of latent spores of Clostridium chauvoei in the muscles of bovines. This clostridiosis is a wide-spread sanitary problem that has the potential to cause serious economic losses. This disease mainly affects 6 to 30-month old bovines, when there apparently is a reduction in antibody levels, making the animals susceptible to this disease (Kriek \& Odendaal 2004).

Immunization against blackleg is one of the most important prophylactic measures for cattle rearing throughout the world and has been used since the $19^{\text {th }}$ century (Blobel \& Schliesser 1980). Though vaccination is done voluntarily, cattle producers recognize the importance of this preventative measure. In Brazil, according to current data provided by the National Syndicate of the Production of Animal Products (Sindan), about 150 million doses of vaccine are sold per year; these include monovalent and polyvalent formulations, all containing $C$. chauvoei.

Since the 1980s, the Ministry of Agriculture, Livestock and Food Supply (MAPA) has evaluated commercial lots of vaccine against blackleg, determining their efficiency in tests made with guinea pigs challenged with a lineage of $C$. chauvoei denominated MT (Brasil 1997). During this period, substantial changes have been made in the formulation of commercial vaccines against blackleg, evolving from monovalent imunogens produced in the country, to complex polyvalent formulations, in order to protect against various clostridioses and multiple species, with importation of part of the vaccine material. The prescription for the use of these commercial bacterins and polyvalent toxoids in this country indicates a need for a booster shot 30 days after the first injection (Sindan 2010). However, operational difficulties in the open-field beef cattle rearing system used in Brazil makes it difficult to apply the recommended booster shots.
Consequently, it is common practice in the southeastern and central west regions of the country to apply a single vaccination dose at weaning (eight months of age).

There is very little information available concerning the serological response of cattle against $C$. chauvoeistimulated by vaccination; that and the increasing production and use of complex polyvalent vaccines, the need to objectively understand the normal vaccine protocols and the economic importance of blackleg, prompted us to evaluate the serological response of beef calves submitted to different vaccination regimens against blackleg. A commercial polyvalent vaccine was used, with two different bacterial strains as antigens.

\section{MATERIALS AND METHODS}

Vaccine. The calves were vaccinated with an imported polyvalent vaccine that is approved by the Ministry of Agriculture, Livestock and Food Supply (MAPA). This vaccine against blackleg contained, along with Clostridium chauvoei, bacterins and toxoids of other clostridial bacteria (aluminum hydroxide adjuvant); it was stored in a refrigerator and applied according to the manufacturer's instructions in aliquots of $5 \mathrm{ml}$, or according to the research protocol.

Vaccination and serological evaluation schemes. Serological evaluations were made of 60 mixed breed calves (Nelore, Aberdeen Angus, Brahman and Red Angus), born during the first 20 days of June 2007, the mothers of which were multiparous Nelore cattle that had been submitted to the normal sanitary management of the farm, which consisted of two annual vaccinations against blackleg (May and November). The calves that were to be immunized were randomly divided into three groups ( $n=15$ each) and were submitted to one of three different vaccination regimens. Group 1 (G1) was vaccinated at four months and a booster shot was given at weaning (8 months). Group 2 (G2) was first vaccinated at weaning and received the booster shot 30 days later. Group 3 was vaccinated with a single dose of the vaccine at weaning. The control group $(n=15)$ was not vaccinated. The blood samples were collected from the external jugular vein with Vacutainer ${ }^{\circledR}$ tubes, which were maintained at room temperature until complete retraction of the coagulum. They were then centrifuged to obtain the serum, which was maintained in a freezer $\left(-20^{\circ} \mathrm{C}\right)$ until the serological tests. The serum collections were made at 4, 8, 9 and 10 months of age.

Clostridium chauvoei strains. The serological evaluation was made with antigens that consisted of two different strains of $C$. chauvoei: the reference strain, denominated MT and a field isolate that came from a disease epidemic associated with vaccine failure (Santos 2003). The reference strain (MT) was supplied by MAPA. The natural epidemic isolate was identified by PCR and maintained in the bacterial library of the Infectious Diseases Laboratory of the Department of Animal Production, Health, and Husbandry, Araçatuba Campus of Unesp.

Immunoenzymatic test (Elisa). The positive serum used to standardize the serological test was obtained from two 18-monthold bovines that had been immunized with three doses of commercial polyvalent vaccine against clostridioses, with a 15day interval between vaccinations. The negative serum sample used in the Elisa test was obtained from a new-born calf, before it had fed on colostrum. The antigens from the reference strain (MT) and from the field-collected strain were standardized as recommended by Crichton et al. (1990).

The 96-hole microplates (Nunc ${ }^{\circledR}$ ) were sensitized with $100 \mu \mathrm{l} /$ well of antigen diluted in carbonate-bicarbonate buffer, diluted 
1:50, and incubated in a humid chamber for 12 hours at $4^{\circ} \mathrm{C}$. Soon after this step, the plates were submitted to three rinses with $0.05 \%$ PBS Tween (PBS-T) in an automatic pipette washer. The reaction was then blocked with $200 \mu \mathrm{l} /$ well of reconstituted $10 \%$ powdered milk (Molico ${ }^{\circledR}$ ) diluted in the carbonatebicarbonate buffer. The plates were then incubated in a humid chamber at $37^{\circ} \mathrm{C}$ for 45 minutes, and submitted to the rinse cycle. Then $100 \mu \mathrm{l}$ of the test and control sera diluted 1:100 in PBS $+10 \%$ powdered milk. Two wells were left without sera; only the buffer was added. This was the plate control (blank). After this step, the plates were incubated at $37^{\circ} \mathrm{C}$ for 60 minutes, and they were then run through the rinse cycle. Then, $100 \mu$ of commercial immunoenzyme conjugate SIGMA ${ }^{\circledR}$ ) was added to each well (this consisted of anti-bovine IgG rabbit serum conjugated with peroxidase, diluted $1: 10,000$ in PBS $+10 \%$ powdered milk); the plates were incubated at $37^{\circ} \mathrm{C}$ for 90 minutes and were again rinsed three times. Immediately afterward, $50 \mu \mathrm{l}$ of ortho-phenylenediamine substrate, diluted in citrate-phosphate buffer, was added. The reaction was interrupted after 15 minutes with $2 \mathrm{M} \mathrm{HCl}(50 \mu \mathrm{l} /$ well), and the readings made with a microplate spectrophotometer (Labsystem - Multiskan EX ${ }^{\circledR}$ ), with a 492nm filter.

Statistical analysis. The Elisa data was transformed by log $(x+1)$ and submitted to analysis of variance with repeated measures and residual analysis to check for normality and homogeneity of the variance, which are prerequisites for analysis of variance. The means were compared with the Tukey test and the differences were considered significant when $\mathrm{p}<0.05$. The statistical analyses were made with the Statistical Analysis System (SAS 1999).

\section{RESULTS}

The three vaccination regimens significantly $(p<0.05)$ increased the serum antibody levels soon after the initial vaccination and after the booster shot (Table 1, Fig.1-2). The mean serum antibody levels in the calves first vaccinated at four months of age (G1) did not differ from the control group, when evaluated at eight months. In this same group, when the booster shot was given at eight months, there was a significant increase in serum antibody levels after 30 days,

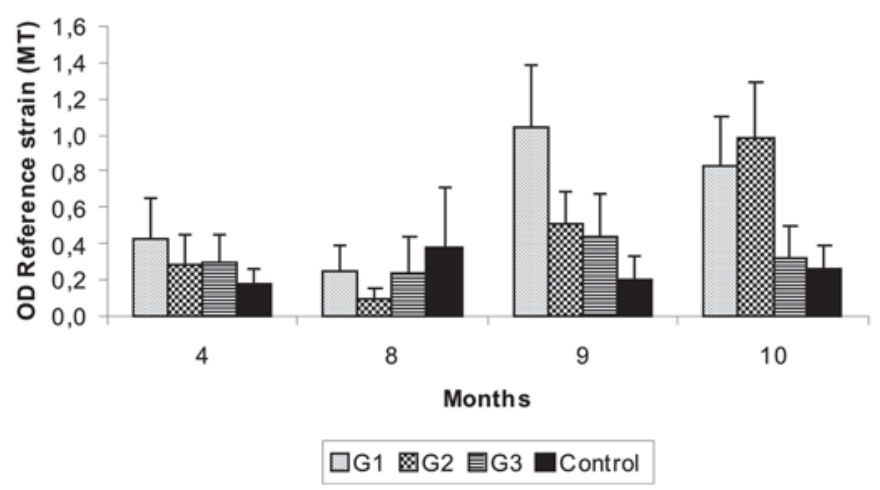

Fig.1. Serological response of calves induced by a commercial imported polyvalent vaccine against clostridiosis, expressed in optical density units (OD) in an Elisa test using a reference (MT) strain of Clostridium chauvoei, and three different vaccination regimens (G1, G2 and $\mathrm{G} 3$ ).

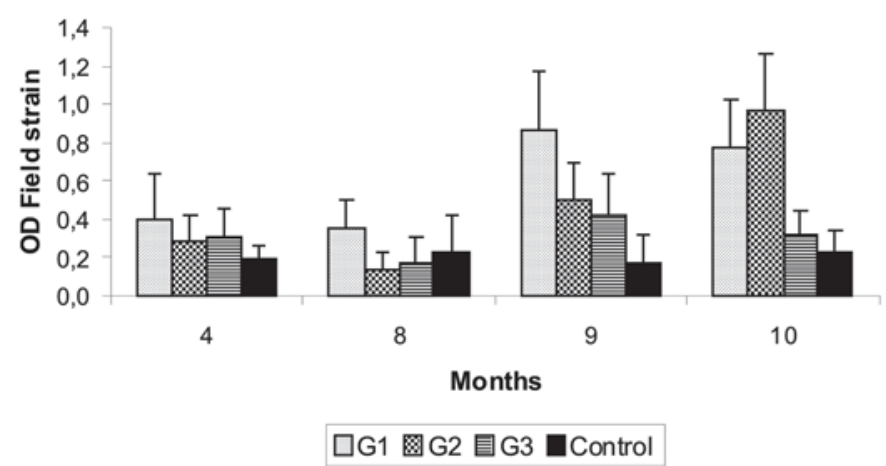

Fig.2. Serological response of calves induced by a commercial imported polyvalent vaccine against clostridiosis, expressed in optical density units (OD) in an Elisa test using a fieldcollected strain of Clostridium chauvoei, and three different vaccination regimens (G1, G2 and G3).

different from what was found for the other two groups (G2 and G3) that were evaluated at nine months. In the evaluation

Table 1. Mean values \pm standard deviation of the serological response of calves vaccinated with commercial imported polyvalent vaccine against clostridiosis, expressed in optical density units (OD) in an Elisa test using reference (MT) and field-collected strains of Clostridium chauvoei, using three different vaccination regimens (G1, G2 and G3)

\begin{tabular}{cccccc}
\hline Strain & Group & \multicolumn{4}{c}{ Age of the calves (months) } \\
\cline { 3 - 6 } & & 4 & 8 & 9 & 10 \\
\hline \multirow{2}{*}{ MT } & G1 & $0.424 \pm 0.227 \mathrm{aB}$ & $0.256 \pm 0.133 \mathrm{abB}^{*}$ & $1.045 \pm 0.336 \mathrm{aA}^{*}$ & $0.830 \pm 0.275 \mathrm{aA}^{*}$ \\
& $\mathrm{G} 2$ & $0.289 \pm 0.161 \mathrm{abC}$ & $0.101 \pm 0.060 \mathrm{bD}^{*}$ & $0.504 \pm 0.183 \mathrm{bB}$ & $0.986 \pm 0.310 \mathrm{aA}$ \\
& $\mathrm{G} 3$ & $0.299 \pm 0.156 \mathrm{abAB}$ & $0.240 \pm 0.193 \mathrm{abB}$ & $0.447 \pm 0.231 \mathrm{bA}$ & $0.325 \pm 0.169 \mathrm{bAB}$ \\
& Control & $0.178 \pm 0.082 \mathrm{bB}$ & $0.386 \pm 0.325 \mathrm{aA}^{*}$ & $0.203 \pm 0.132 \mathrm{cB}^{*}$ & $0.266 \pm 0.125 \mathrm{bAB}^{*}$ \\
Field & $\mathrm{G} 1$ & $0.401 \pm 0.237 \mathrm{aB}$ & $0.356 \pm 0.146 \mathrm{aB}$ & $0.865 \pm 0.307 \mathrm{aA}$ & $0.772 \pm 0.254 \mathrm{aA}$ \\
& $\mathrm{G} 2$ & $0.282 \pm 0.141 \mathrm{abC}$ & $0.140 \pm 0.088 \mathrm{bC}$ & $0.497 \pm 0.193 \mathrm{bB}$ & $0.970 \pm 0.296 \mathrm{aA}$ \\
& $\mathrm{G} 3$ & $0.314 \pm 0.141 \mathrm{abA}$ & $0.171 \pm 0.141 \mathrm{bB}$ & $0.427 \pm 0.210 \mathrm{bA}$ & $0.318 \pm 0.126 \mathrm{bA}$ \\
& Control & $0.192 \pm 0.068 \mathrm{bA}$ & $0.230 \pm 0.185 \mathrm{abA}$ & $0.179 \pm 0.139 \mathrm{cA}$ & $0.231 \pm 0.112 \mathrm{bA}$
\end{tabular}

Means followed by different letters (lower case in the column and upper case in the row) are significantly different (Tukey test, $\mathrm{p}<0.05$ ).

* Significantly different from the field-collected strain $(p<0.05)$.

G1 = vaccinated at 4 and 8 months; G2 = vaccinated at eight and nine months; G3 = vaccinated at eight months; Control $=$ not vaccinated 
of the serological response at 10 months, no difference was observed between calves vaccinated at four and eight months (G1) and those that were vaccinated at eight months and given a booster shot 30 days later (G2).

The mean serum antibody levels in calves first vaccinated at eight months of age and given a booster shot 30 days later (G2), did not differ from those in calves vaccinated only at eight months (G3), when they were evaluated at nine months. This same group had significantly higher serum antibody levels when evaluated 30 days later, though at 10 months they did not differ from the control group (Table 1, Fig.1-2).

When the serological test was done using the field-collected strain of $C$. chauvoei, the mean serum antibody values were significantly lower at two evaluation times among calves first vaccinated at four months and given a booster shot at eight months (G1); this was also found at one evaluation time only among calves that had only been vaccinated at eight months (G3), and at three evaluation times among the control calves. When the reference strain (MT) was used, the mean serum levels were significantly lower at one evaluation time among calves that were first vaccinated at four months and given a booster shot at eight months (G1); and also at one evaluation time among calves that were vaccinated at eight months and had a booster shot 30 days later (G2, Table 1).

\section{DISCUSSION}

Vaccination is the principal prophylactic measure used to avoid bovine mortality caused by Clostridium chauvoei. Though it is not obligatory, the benefits of immunization against blackleg are widely known by technical personnel and by rural producers. According to Kriek \& Odendaal (2004), vaccination of bovines can be done from four-months of age on, with a booster shot 30 days later, followed by annual vaccination, which guarantees protection until three years of age.

In Brazil, commercial products that contain $C$. chauvoei are analyzed by MAPA since the 1980s, through testing in guinea pigs. Only vaccines that protect at least seven of eight vaccinated guinea pigs are approved for commercialization (Brasil 1997). In this context, the general perception is that the vaccines used to control blackleg effectively contribute to prophylaxis against this disease. However, various important aspects related to what actually happens in the field, and how the commercial products are formulated, remain unknown or poorly studied.

Bacterins from $C$. chauvoei evaluated as excellent, marginal or weak in the test for potency using guinea pigs protect as well or better in bovines subjected to an experimental challenge (Macheak et al. 1972). Though the challenge tests are more adequate for vaccine quality control, there is a correlation between the agglutinating antibody titers and the protective immunity in animals against a bacterial challenge (Claus \& Macheak 1972); the concordance between the agglutination tests and the Elisa test for measuring the serological response in bovines vaccinated against blackleg is greater than $90 \%$ (Araujo 2009). Elisa has also proved to be an appropriate tool for determining the potential of vaccines that contain C. chauvoei antigens (Crichton et al. 1990).
Based on the serological response of the calves vaccinated with the commercial polyvalent vaccine, it can be seen that an initial vaccination at four months and a booster shot at weaning (Table 1) is equivalent to the vaccination scheme indicated by the company that makes the vaccines and is significantly superior to what is being used in the field. In an initial analysis, besides facilitating sanitary management in open field cattle rearing, and the fact that this is new information concerning refrigerated vaccines, this vaccination regimen (G1) was found to be superior when evaluated 30 days after the booster (Fig.1-2). Even though the minimum concentration of antibodies necessary to protect the animals against natural challenges by $C$. chauvoei is unknown, these levels could be sufficient to provide adequate immunity for the herd under normal conditions, during this period of greater susceptibility to disease. However, it will be necessary to determine how the immune response develops at later ages, as well as the epidemiological behavior of this disease under field challenge situations, conditions that were not included in this study.

The serological response to a field-strain antigen was measured because previous tests had shown different degrees of protection in guinea pigs vaccinated with different commercial products. Santos (2003) reported that 21 of 22 vaccine lots provided immune protection to guinea pigs challenged with MT strain; when the challenge was made with a field-strain antigen, only eight of the 22 had adequate protection levels. There were also differences in the serological response of animals challenged with this same field strain in this research (Table 1). This is important information for vaccine producers and for government agencies that regulate the commercialization of these vaccines in this country.

The complex antigenic composition of $C$. chauvoei, combined with a lack of information concerning which bacterial strains are used for producing the commercial vaccines, make it difficult to objectively evaluate these products, which according to Mayr et al. (1984) should be made with local bacterial strains in order to guarantee their efficacy. It is understood that protective immunity against $C$. chauvoei is mainly antibacterial and to a lesser extent antitoxic; however, it is unknown to what extent each type of immunity is stimulated by the vaccinations (Chandler \& Gulasekharam 1970, Crichton et al. 1990). Immunologically, it is unknown which factor actually confers better protection against the extremely varied challenges and whether these antigenic factors could be used as immunogens. In fact, the vaccines used against blackleg are bacterins and they contain antigens from the whole culture material of the microorganism (Stevenson \& Stonger 1980). These particularities of this bacterium could be reasons for the diverse results when they are evaluated with distinct bacterial strains, both in the challenge test and when the serological response is evaluated.

Among the relevant factors in the development of immunity against $C$. chauvoei, the most important is protection provided by vaccines made from strains that are homologous to those in the local environment (Schipper et al. 1978). Vaccination with homologous strains gives better protection against a 
homologous challenge than against a heterologous challenge, though some strains produce immunity with a wider spectrum of protection than do others (Kerry 1967). Consequently, it appears that the antigenic identity of the bacterial strain used to produce the polyvalent vaccine used in this research was similar to that of strain MT. However, at some evaluation times, the serological response to the field strain was inferior, which could be decisive in cases of intense bacterial challenge by local strains.

Along this line of reasoning, it would appear that the ideal situation would be introduction of regional field strains for the production of commercial products, along with improved epidemiological vigilance, as proposed by Chandler (1976). In Australia, this strategy has been used since the 1970s, after heavy cattle losses, probably due to vaccine failure (Reed \& Reynolds 1977). Also, it would be useful to implement systems for early reporting of disease outbreaks, including information about the field strains of $C$. chauvoei that are involved (Dodson 1978).

The substantial and complex changes in the formulations of the vaccines against blackleg, not always following a technical rationality, can generate high-risk situations in disease prophylaxis. Consequently, it is important to be sure that the immunogenicity of $C$. chauvoei in complex polyvalent vaccines is sufficient not only for official tests, but that they also protect the animals against field strains. Vaccinating calves at four and eight months gave a satisfactory serological response. However, the efficiency of this response was significantly compromised when a field strain of the bacteria was used as a test antigen.

Acknowledgements.- To Professors Tereza Cristina Cardoso and Sílvia Helena Venturoli Perri, along with technicians Adão Ângelo Custódio, Gilmara Castilho and Alessandra Mara Alves Ragozo, of the Universidade Estadual Paulista, Campus Araçatuba, for helping collect sera and for their help in the laboratory; to the company Agropecuária Estrela do Céu that helped with the field work, and also to Coordenação de Aperfeiçoamento de Pessoal de Nível Superior (CAPES) for a Master of Science scholarship.

\section{REFERENCES}

Araujo R.F. 2009. Resposta sorológica de bovinos vacinados contra o Clostridium chauvoei avaliada pelos testes de aglutinação em placa e ELISA. Dissertação de Mestrado em Medicina Veterinária Preventiva, Faculdade de Ciências Agrárias e Veterinárias, Universidade Estadual Paulista, Jaboticabal, SP. 58p.
Brasil 1997. Ministério da Agricultura, Pecuária e Abastecimento (MAPA). Portaria no 49 de 12 de maio de 1997, Seção 1, p.10168. Brasília.

Blobel H. \& Schliesser T. 1980. Clostridiosen der Haustiere, p.555666. In: Ibid. (Eds), Handbuch der Bakteriellen Infektionen bei Tieren. Band II. Gustav Fischer Verlag, Stuttgart.

Chandler H.M. 1976. Some observations on the quality control testing of Clostridium chauvoei vaccines. Dev. Biol. Stand. 82:137-141.

Chandler H.M. \& Gulasekharam J. 1970. An evaluation of characteristics of Clostridium chauvoei, which possibly indicate a highly protective strain. Aust. J. Exp. Biol. Med. Sci. 48:187-197.

Claus K.D. \& Macheak M.E. 1972. Preparation of a Clostridium chauvoei antigen and determination of protective immunity by plate agglutination test. Am. J. Vet. Res. 33:1045-1052.

Crichton R., Solomon J. \& Barton A.M. 1990. The Development of an Enzyme-linked Immunosorbent Assay for measuring the potency of vaccines containing Clostridium chauvoei antigens. Biologicals 18:49-54

Dodson L.F. 1978. Failure of Clostridium chauvoei vaccines to protect against blackleg. Aust. Vet. J. 54:598.

Kerry J.B. 1967. Immunological differences between strains of Clostridium chauvoei. Res. Vet. Sci. 8:89-97.

Kriek N.P.J. \& Odendaal M.W. 2004. Clostridium chauvoei infections, p.1856-1862. In: Coetzer R. \& Tustin R.C. (Eds), Infectious Diseases of Livestock. Vol.3. $2^{\text {nd }}$ ed. Oxford University Press, Cape Town.

Macheak M.E., Claus K.D. \& Maloy S.E. 1972. Potency testing Clostridium chauvoei - containing bacteris: Relationship of agglutination titers and potency tests in cattle. Am. J. Vet. Res. 33:1053-1058.

Mayr A., Eissner G. \& Mayr-Bibrack B. 1984. Clostridiosen, p.871894. In: Ibid. (Eds), Handbuch der Schutzimpfungen in der Tiermedizin. Verlag Paul Parey, Berlin.

Reed G.A. \& Reynolds L. 1977. Failure of Clostridium chauvoei vaccines to protect against blackleg. Aust. Vet. J. 53:393.

Santos B.A. 2003. Avaliação da eficácia em cobaias de imunógenos contra carbúnculo sintomático em uso no Brasil. Dissertação de Mestrado em Medicina Veterinária Preventiva, Faculdade de Ciências Agrárias e Veterinárias, Universidade Estadual Paulista, Jaboticabal, SP. 35p.

SAS Institute 1999. SAS OnlineDoc ${ }^{\circledR}$, Version 8. Cary.

Schipper I.A., Kelling C.L., Mayer J. \& Pfeiffer N.W. 1978. Effects of passive immunity on immune response in calves vaccinated against Clostridium chauvoei infection (blackleg). Vet. Med. Small Anim. Clin. 73:1564-1566.

Sindan 2010. Compêndio de Produtos Veterinários-Sindan. Sindicato Nacional da Indústria de Produtos para Saúde Animal. Disponível em: http://www.sindan.org.br/sd/sindan/index.html. Acesso em 31.3.2010.

Stevenson J.R. \& Stonger K.A. 1980. Protective cellular antigen of Clostridium chauvoei. Am. J. Vet. Res. 41:650-652. 